\title{
PERANAN STRATEGI PEMASARAN DALAM UPAYA MENINGKATKAN PENJUALAN PRODUK BATU CETAK
}

\author{
Muhammad Syahrun \\ Email: torighgifari@gmail.com \\ Program Studi Pendidikan Ekonomi IKIP Muhammadiyah Maumere
}

\begin{abstract}
ABSTRAK
Penelitian ini bertujuan untuk mengetahui peranan strategi pemasaran dalam menghadapi persaingan bisnis yang sangat kompetitif, selain itu untuk mengetahui pelaksanaan strategi yang telah dilakukan perusahaan. Untuk itu dipandang perlu mendesain strategi secara menyeluruh dalam kegiatannya agar perusahaan memiliki strategi yang efektif dalam rangka meningkatkan volume penjualan. Penelitian ini dilakukan di Kabupaten Sikka, tepatnya di pelaku Industri UD. Rajawali Sakti. Teknik pengumpulan data yang digunakan adalah wawancara dan dokumentasi, metode yang digunakan dalam penelitian ini adalah metode analsis kualitatif, sedangkan tipe penelitiannya adalah menjelaskan peranan strategi pemasaran dalam upaya meningkatkan penjualan. Hasil penelitian menunjukan penjualan produk batu cetak mengalami kenaikan dan dijadikan acuan dalam strategi pemasaran.
\end{abstract}

Kata Kunci: Strategi Pemasaran, produk, promosi, harga, dan tempat.

ABSTRACT

This study aims to determine the role of marketing strategy in facing a very competitive business competition, in addition to knowing the implementation of strategies that have been carried out by the company. For this reason, it is deemed necessary to design a comprehensive strategy in its activities so that the company has an effective strategy in order to increase sales volume. This research was conducted in Sikka Regency, specifically on UD Industry players Holy Eagle. The data collection technique is interview and documentation approach, while the type of research is qualitatif analysis. The results of the analysis of the role of marketing strategy show an overall increase in the sales volume of printed stone products, and is used as a reference in marketing strategies.

Keywords: Marketing Strategy, product, promotion, price and place.

\section{PENDAHULUAN}

Aktivitas perekonomian yang dilakukan industri kecil merupakan suatu upaya untuk meningkatkan pendapatan Nasional baik untuk Industri itu sendiri maupun untuk Negara. Keberadaan Industri kecil merupakan bagian dari variabel ekonomi yang dapat meningkatkan kapasitas perekonomian secara nasional, selain itu diyakini dapat mempercepat pertumbuhan ekonomi, karena dapat mempercepat pemerataan ekonomi dalam menyediakan lapangan kerja dan menyerap tenaga kerja, sehingga dapat meningkatkan pendapatan masyarakat serta memberi efek tehadap struktur industri nasional. Meningkatnya kegiatan bisnis yang dijalankan pelaku ekonomi menunjukan adanya perubahan jumlah barang dan jasa yang diperjual belikan, kondisi ini memperkuat bahwa persaingan bisnis perlu adanya strategi bisnis yang mampu menjawab tantangan dan hambatan dalam menciptakan nilai tambah dari pergerakan kegiatan bisnis. 
Selain itu dalam aktifitas bisnis pengusaha cendrung menciptakan varian produk baru agar mampu bersaing dengan produk - produk batu cetak yang diproduksi oleh perusahaan lainnya yang ada di pasaran. Peersaingan yang dihadapi UD. Rajawali Sakti dalam produk batu cetak sangat ketat, oleh karena itu perusahaan menyadari persaingan tersebut maka dengan menggunakan konsep bisnis yang bagus dan didukung dengan manajemen yang baik maka perusahaan dapat memenuhi kebutuhan masyarakat dalam menghadapi persaingan bisnis yang semakin ketat. Oleh karena itu kreatifitas dan inovasi yang selalu di perbaharui oleh perusahaan akan memberikan efek terhadap penjualan produk bagi industri percetakan batu.

Formulasi pemasaran didesain dengan tujuan agar produk yang dijual di pasaran dapat memberikan kemudahan bagi konsumen dalam memilih dan memilah produk mana yang dapat memberikan kepuasan bagi konsumen, oleh karena itu corak dan karakteristik dapat membantu konsumen untuk melakukan pembelian ulang secara terus menerus, sehingga dari hasil penjualan produk tersebut dapat meningkatkan volume penjualan. Dengan meningkatnya volume penjualan tersebut, mengindikasikan bahwa strategi bauran pemasaran (produk, harga, promosi, dan tempat/lokasi) berjalan efektif dan maksimal, selain itu di pengaruhi juga oleh faktor pelayanan prima, harga terjangkau, serta motif atau desain produk yang mengikuti trend.

Keberhasilan perusahaan dalam menerapkan strategi pemasaran merupakan tolok ukur dalam memproduksi produk dan jasa secara masal sehingga dapat dinilai terciptanya hubungan yang baik dengan konsumen. Persaingan bisnis dalam pemasaran barang dan jasa menyebabkan perusahaan dituntut terus berkembang dalam menciptakan produk, sehingga perusahaan dapat menjaring konsumen lebih banyak lagi, untuk itu kegitan bisnis ini menjadi bagian dari pemenuhan pasar sebagai terciptanya hubungan yang baik dengan konsumen. Berbagai cara dan strategi pemasaran pun dilakukan oleh para produsen agar meningkatkan hasil penjualan. Formulasi pemasaran merupakan intisari dari kegiatan pemasaran dalam rangka pemenuhan keinginan konsumen (Tjiptono C. , 2012) dalam Sudaryono (2016:38).

Kegiatan bisnis yang dijalankan oleh pelaku ekonomi merupakan bagian dari pemasaran dalam rangka untuk menjaring konsumen, strategi tersebut dijalankan agar perusahaan dapat bersaing dan bahkan dapat memenangkan persaingan ditengah semakin moderennya formulasi bisnis dalam pemasaran. Oleh karena itu pemilihan strategi harus disesuaikan dengan kebutuhan pasar agar dapat mempengaruhi konsumen dalam keputusan pembelian produk. Karenanya kita memandang strategi pemasaran merupakan bagian dari 
ilmu pemasaran dalam memetakan sasaran yang ingin dicapai oleh perusahaan dalam menciptakan hubungan yang baik diantara konsumen dan perusahaan, sehingga terciptanya pelanggan yang unggul (Abdurrahman N. H., Manajemen strategi pemasaran, 2015)

Banyaknya produk batu cetak yang beredar dipasaran menyebabkan persaingan dagang di pasaran semakin kopetitif, untuk itu perusahaan harus memiliki konsep bisnis yang baik sehingga dapat menjawab kebutuhan dan keinginan pasar. Didalam pasar persaingan produk batu cetak sangat kompetitif oleh karena itu perusahaan UD. Rajawali Sakti menggunakan strategi bauran pemasaran, hal ini agar dapat menarik pembelian yang dilakukan oleh konsumen.

Strategi pemasaran yang dilakukan perusahaan adalah dengan menggunakan pendekatan strategi Produk (produck), yaitu perusahaan menawarkan jenis barang dengan berbagai macam varian batu cetak yang ditawarkan pada pasar agar menarik konsumen sehingga dapat memberikan kepuasan pada konsumen. Penawaran produk pada pasar merupakan bagian dari strategi pasar agar produk tersebut dapat dikenal di pasaran. Faktor promosi (promotion) merupakan bagian dari usaha perusahaan dalam memperkenalkan produk pada konsumen, dimana kegiatan yang dilakukan perusahaan UD. Rajawali Sakti, dengan menggunakan saluran pemasaran berupa media iklan, spanduk serta media sosial. Sarana yang dilakukan perusahaan ini dapat memberikan efek terhadap penjualan produk batu cetak. Strategi pemasaran selanjutnya adalah harga (price), merupakan bagian dari konsekwensi dimana ketika perusahaan menawarkan produk batu cetak maka sebagai kompensasi nya adalah konsumen menyerahkan sebagian pendapatannya berupa nilai dari barang yang diperolehnya di pasar.

Oleh karena itu hasil pertukaran yang dilakukan oleh produsen dan konsumen berupa varian batu cetak, dapat memberikan kepuasan kepada konsumen. penetapan harga tersebut dapat meberikan nilai lebih kepada konsumen mengingat persaingan harga di pasar sangat kompetitif, sehingga dapat memberikan citra baik pada perusahaan. Salah satu factor penting dalam aktifitas bisnis adalah tempat (place) atau keberadaan perusahaan tersebut, dimana lokasi usaha yang strategis dan dapat terjangkau oleh konsumen dan akses trasnportasi ke perusahaan, tempat atau lokasi bisa diartikan sebagai pemilihan tempat usaha dan pemilihan tempat untuk pelayanan usaha.

Pemasaran perlu mendapatkan perhatian yang serius oleh UD. Rajawali Sakti, mengingat persaingan dalam dunia bisnis yang cendrung berubah sesuai dengan perkembangan pemasaran yang ada, untuk itu strategi pemasaran menjadi pilihan utama 
sehingga produk -produk yang dihasilkan dapat bersaing dipasaran. Dengan demikian strategi yang matang akan memberikan dampak kelangsungan hidup perusahaan percetakan batu itu sendiri. Untuk mendapatkan keuntungan yang maksimal, maka perusahaan harus dapat menjalankan strategi pemasaran dengan baik. Keadaan ini tidak terkecuali akan dihadapi percetakan batu UD. Rajawali Sakti, dimana manajemen dapat melakukan perumusan strategi pemasaran dalam upaya memperluas jaringan pasar.

\section{METODE PENELITIAN}

\section{Jenis dan Sumber Data}

Penelitian ini menggunakan motode kualitatif, yaitu untuk mendapatkan informasi yang mendalam dari setiap informasi yang di peroleh diharapakan informan dapat memberikan informasi yang bermanfaat terkait dengan penelitian, selanjutnya data yang diperoleh akan diolah untuk menjadi bahan masukan peneliti, sehingga dapat memberikan terpenuhinya unsur - unsur psikologis baik kepada sesorang maupun kepada kelompok, (Sugiono 2012). Sumber data utama dalam penelitian kualitatif berupa kata - kata, sedangkan tindakan merupakan perilaku tambahan untuk mengumpulkan data yang diperoleh dari lapangan (Lexy J. M., Metodelogi penelitian Kualitatif, 2012). Sumber data primer adalah sumber pertama dimana sebuah data dihasilkan (Bungin, 2013). Data yang diperoleh dalam penelitian ini adalah data primer dan data sekunder. Data primer diperoleh langsung peneliti dilapangan dengan mengadakan wawancara langsung dengan pemilik perusahaan dan Agen atau Distributor serta pengecer. Sedangan Data sekunder adalah data yang diperoleh dari dokumen, laporan atau langsung dari pihak yang berwewenang

Teknik pengumpulan data adalah mekanisme yang harus dilakukan oleh peneliti dalam mengumpulkan data, yang merupakan langkah paling startegis dalam penelitian, karena tujuan penelitian adalah mendapatkan data (Boedi Abdullah, 2014). Maka dalam penelitian ini menggunakan teknik pengumpulan data: pertama, wawancara adalah teknik pengumpulan data melalui proses Tanya jawab lisan yang berlangsung satu arah, artinya pertanyaan dari pihak yang mewawancarai dan jawaban diberikan oleh yang diwawancara (Nasution, Metode Resech, 2015). Jenis wawancara yang digunakan dalam penelitian ini adalah wawancara tidak berstruktur dengan menggunakan pertanyaan terbuka. Kedua, dokumentasi yaitu dengan mengumpulkan data dan mempelajari data-data yang relevan dan mendukung dalam penelitian, antara lain diperoleh dari UD. Rajawali Sakti 
Metode yang digunakan dalam dalam penelitian ini adalah metode analisa kualitatif karena data yang diperoleh berupa keterangan-keterangan dalam bentuk uraian. Berdasarkan keterangan diatas maka dalam menganalisa data penulis menggunakan data yang diperoleh dari data primer dan data sekunder. Data tersebut kemudian dianalisis dengan menggunakan metode berfikir induktif. Metode berfikir induktif adalah metode berfikir yang dimulai dari fakta empiris. Peneliti terjun ke lapangan, mempelajari, menganalisis, menafsirkan, dan menarik kesimpulan dari fenomena yang ada di lapangan Nurul Zuriah (2013).

\section{HASIL DAN PEMBAHASAN}

\section{Hasil}

\section{Strategi Pemasaran Dalam Meningkatkan Penjualan Batu Cetak}

Strategi pemasaran yang dilakukan oleh UD. Rajawali Sakti dalam memasarkan produknya yaitu dengan menggunakan perumusan strategi pemasaran dengan pendekatan strategi bauran pemasaran.

\section{Produk}

Produk merupakan kombinasi barang atau jasa yang ditawarkan oleh perusahaan kepada pasar sasaran. Segmentasi pasar memandang produk baik adalah bagaimana produk memberikan solusi bagi kebutuhan dan keinginan konsumen (Suharno dan Santoso, 2010). Strategi penting dalam memasarkan suatu produk adalah kualitas barang atau jasa. Hal ini telah dilakukan UD. Rajawali Sakti yang selalu mengutamakan kualitas barang atau jasa dimana kombinasi bahan baku telah dilakukan dengan menggunakan mesin tenaga listrik, sehingga produk yang dihasilkan memiliki kualitas yang baik dan bertahan lama. Selain itu pengembangan inovasi terus dilakukan UD. Rajawali Sakti untuk menghasilkan varian batu cetak yang lebih artistic. Dari hasil penelitian tersebut menunjukan bahwa startegi produk sangat berdampak pada keuntungan yang maksimal.

\section{Promosi}

Promosi merupakan bagian dari aktifitas perusahaan dalam rangka meningkatkan dan mempertahankan kreatifitas dan inovasi usaha demi menarik minat konsumen termasuk melakukan kegiatan promosi. Kegiatan promosi ini dilakukan dengan menggunakan media Iklan, spanduk serta Facebook.

Dengan berkomunikasi baik menggunakan promosi maupun Iklan UD. Rajawali Sakti juga menggunakan promosi dari mulut kemulut. Selain itu strategi yang digunakan 
memberikan dampak yang signifikan terhadap keuntungan yang diperoleh UD. Rajawali Sakti.

\section{Harga}

Penetapan harga dalam strategi pemasaran merupakan komponen penting dalam menentukan arah kebijakan perusahaan, mengingat harga di tentukan berdasarkan perhitungan dari biaya keseluruhan yang dikeluarkan oleh UD. Rajawali Sakti. Harga yang ditentukan UD. Rajawali Sakti ditentukan sesuai dengan desain, bahan dan tingkat kesulitan yang dihadapi perusahaan dalam memproduksi barang. Harga batu cetak sangat bervariasi dari Rp. 2.500 - Rp. 150.000. Harga batu cetak sangat kompetitif dipasaran, mengingat perusahaan yang sejenis cukup banyak sehingga tidak ada yang monopoli dalam penetepan harga. Namun yang menjadi pembeda dengan perusahaan lainnya, bahwa di UD. Rajawali Sakti memiliki keunggulan lebih selain kualitas batu cetaknya, keunggulain lainya yaitu pelayanan pengantaran orderan baik di dalam kota maupun di luar kota mendapat bonus atau potongan biaya yang dikeluarkan oleh konsumen.

\section{Tempat}

Salah satu factor penting dalam aktifitas Bisnis adalah lokasi atau keberadaan perusahaan tersebut, dimana lokasi usaha yang strategis dan dapat terjangkau oleh konsumen dan akses trasnportasi ke perusahaan, tempat atau lokasi bisa diartikan sebagai pemilihan tempat usaha dan pemilihan tempat untuk pelayanan usaha. Lokasi berfungsi sebagai usaha menghitung sejauh mana lokasi akan mempengaruhi pembelian konsumen (Suharno dan Santoso, Marketing in practice, 2010). UD. Rajawali Sakti merupakan salah satu usaha yang berada di lokasi pusat pengembangan bisnis dan berada di pinggir jalan utama.

\section{Volume Penjualan Batu Cetak}

Dalam aktifitas bisnis strategi pemasaran merupakan komponen yang paling penting. Salah satu analisa terpenting yang dilakukan perusahaan adalah analisis volume penjualan. Dengan analisa tersebut memberikan informasi apakah penjualan produk perusahaan mengalami kenaikan atau penurunan.

Dari data yang diperoleh peneliti di ketahui bahwa UD. Rajawali Sakti dalam kegiatan bisnis dalam satu tahun terakhir mengalami fluktuasi volume penjualan produk batu cetak.

Table 4.1. Penjualan Produk barang UD. Rajawali Sakti tahun 2020 
Jurnal Ekonomi Pembangunan Vol. 7, No.2 (2021) 142-152

\begin{tabular}{|c|c|c|c|c|}
\hline No & Nama barang & $\begin{array}{c}\text { Jumlah } \\
\text { barang/buah }\end{array}$ & Bulan & Total \\
\hline 1 & Paving Blok & 19.950 & \multirow{3}{*}{ Januari } & 66.625 .000 \\
\hline 2 & Batu Boster & 311 & & 3.425 .000 \\
\hline 3 & Batako & 156 & & 624.000 \\
\hline \multicolumn{3}{|c|}{ Total } & & 70.674. 000 \\
\hline 4 & Paving blok & 10.490 & \multirow{5}{*}{ Februari } & 26.127 .000 \\
\hline 5 & Batu Roster & 1737 & & 18.984 .000 \\
\hline 6 & Batako & 663 & & 2.152 .000 \\
\hline \multirow[t]{2}{*}{7} & Pilar tanah & 96 & & 1.440 .000 \\
\hline & & & & 48.703. 000 \\
\hline 8 & Batu Roster & 1116 & \multirow{5}{*}{ Maret } & 11.689 .000 \\
\hline 9 & Paving blok & 4850 & & 12.050 .000 \\
\hline 10 & Batako & 1840 & & 7.360 .000 \\
\hline 11 & Gorong gorong & 74 & & 11.050 .000 \\
\hline 12 & Pilar tanah & 13 & & 195.000 \\
\hline \multicolumn{3}{|c|}{ Total } & & 42.344.000 \\
\hline 13 & Batu Roster & 777 & \multirow{5}{*}{ April } & 7.533 .000 \\
\hline 14 & Paving blok & 3250 & & 7.755 .000 \\
\hline 15 & Batako & 3.385 & & 13.040 .000 \\
\hline 16 & Gorong gorong & 25 & & 3.750 .000 \\
\hline 17 & Pilar tanah & 9 & & 1.350 .000 \\
\hline \multicolumn{3}{|c|}{ Total } & & 33428.000 \\
\hline 18 & Batu Roster & 6 & \multirow{4}{*}{ Mei } & 7.431 .000 \\
\hline 19 & Batako & 2795 & & 11.475 .000 \\
\hline 20 & Pilar tanah & 18 & & 270.000 \\
\hline 21 & Gorong gorong & 23 & & 3.360 .000 \\
\hline \multicolumn{3}{|c|}{ Total } & & 22.536.000 \\
\hline 22 & Batu Roster & 109.000 & \multirow{3}{*}{ Juni } & 9.442 .000 \\
\hline 23 & Paving blok & 33.352 & & 50.000 .000 \\
\hline 24 & Batako & 4380 & & 17.400 .000 \\
\hline
\end{tabular}




\begin{tabular}{|c|c|c|c|c|}
\hline 25 & $\begin{array}{l}\text { Gorong } \quad- \\
\text { gorong }\end{array}$ & 40 & & 5.950 .000 \\
\hline 26 & Pilar tanah & 15 & & 300.000 \\
\hline \multicolumn{3}{|c|}{ Total } & & 83.092 .000 \\
\hline 27 & Batu Roster & 2200 & \multirow{4}{*}{ Juli } & 22.567 .000 \\
\hline 28 & Paving blok & 19800 & & 60.205 .000 \\
\hline 29 & Batako & 1500 & & 6.030 .000 \\
\hline 30 & $\begin{array}{l}\text { Gorong } \\
\text { gorong }\end{array}$ & 9 & & 1.350 .000 \\
\hline \multicolumn{3}{|c|}{ Total } & & 90.152 .000 \\
\hline 31 & Batu Roster & 1500 & \multirow{4}{*}{ Agustus } & 16.927 .000 \\
\hline 32 & Paving blok & 45.000 & & 11.250 .000 \\
\hline 33 & Batako & 2.300 & & 8.410 .000 \\
\hline 34 & $\begin{array}{l}\text { Gorong } \\
\text { gorong }\end{array}$ & 55 & & 9.460 .000 \\
\hline \multicolumn{3}{|c|}{ Total } & & 46.047 .000 \\
\hline 35 & Batu Roster & 1.510 & \multirow{4}{*}{ September } & 13.608 .000 \\
\hline 36 & Paving blok & 4.100 & & 10.250 .000 \\
\hline 37 & Batako & 3.670 & & 12.845 .000 \\
\hline 38 & $\begin{array}{l}\text { Gorong } \\
\text { gorong }\end{array}$ & 35 & & 5.250 .000 \\
\hline \multicolumn{3}{|c|}{ Total } & & 41.953. 000 \\
\hline 39 & Batu Roster & 1690 & \multirow{5}{*}{ Oktober } & 14.892 .000 \\
\hline 40 & Paving blok & 4700 & & 11.750 .000 \\
\hline 41 & Batako & 1100 & & 4. 000.000 \\
\hline 42 & $\begin{array}{l}\text { Gorong } \\
\text { gorong }\end{array}$ & 40 & & 6.500 .000 \\
\hline 43 & Pilar tanah & 4 & & 80.000 \\
\hline \multicolumn{3}{|c|}{ Total } & & 37.142.000 \\
\hline 44 & Batu Roster & 1500 & \multirow{3}{*}{ November } & 19.500 .000 \\
\hline 45 & Paving blok & 300 & & 6.000 .000 \\
\hline 46 & Batako & 4000 & & 14.000 .000 \\
\hline
\end{tabular}




\begin{tabular}{|c|c|c|c|c|}
\hline 47 & $\begin{array}{l}\text { Gorong } \quad- \\
\text { gorong }\end{array}$ & 25 & & 3.750 .000 \\
\hline \multicolumn{3}{|c|}{ Total } & & 43. 000.000 \\
\hline 50 & Paving blok & 3550 & \multirow{4}{*}{ Desember } & 8.875 .000 \\
\hline 51 & Batako & 3500 & & 12.250 .000 \\
\hline 52 & Batu Roster & 350 & & 2.800 .000 \\
\hline 53 & $\begin{array}{l}\text { Gorong } \\
\text { gorong }\end{array}$ & 80 & & 12.000 .000 \\
\hline \multicolumn{3}{|c|}{ Total } & & 35.925 .000 \\
\hline
\end{tabular}

Sumber: Data diolah.

\section{Pembahasan}

Berdasarkan table data penjualan diatas bahwa volume penjualan dari bulan januari sampai bulan Mei menunjukan terjadinya penurunan omset dari Rp. 70.674. 000 menurun sampai Rp. 22.536. 000, kondisi ini tidak terlepas dari situasi perekonomian secara Nasional mengalami pelambatan pertumbuhan ekonomi disebabkan factor Pandemi Covid 19, sehingga berimbas pada perekonomian Daerah, namun pada bulan Juni dan Juli penjualan batu cetak mengalami kenaikan secara signifikan dari Rp. 83.092. 000 menjadi Rp. 90.152. 000. Peningkatan omset penjualan ini dikarenakan permintaan dari sector konstruksi mengalami peningkatan.

Memasuki bulan Agustus sampai dengan bulan Desember trend penjualan batu cetak mengalami penurunan dari Rp. 46.047. 000, sampai Rp. 35.925. 000. Penurunan penjualan batu cetak ini disebabkan kondisi perekonomian belum mampu memperbaiki pendapatan masyarakat, sehingga berpengaruh terhadap daya beli masyarakat.

Penjualan Batu cetak ini jika dilihat dari jenis nya, paling bayak terjual adalah Batu paving blok mencapai Rp. 66.625. 000, sedangkan yang paling sedikit terjual adalah batu cetak jenis Pilar tanah mencapai Rp. 80. 000.

Strategi merupakan rencana yang menyeluruh, terpadu dan menyatu dibidang pemasaran, yang memberikan panduan tentang kegiatan yang akan dijalankan untuk dapat tercapainya tujuan pemasaran suatu perusahaan, Nana herdiana Abdurrahman (2015). Dalam strategi pemasaran yang dilakukan UD. Rajawali Sakti untuk meningkatkan volume penjualan yang dilakukan perusahaan adalah selalu melakukan Inovasi dan kreatif dalam 
memproduksi batu cetak, hal ini dilakukan mengingat bahwa dalam dunia bisnis tentu memiliki pesaing yang gencar melakukan pemasaran.

Volume penjualan dipengaruhi oleh beberapa factor, dimana factor - factor ini merupakan syarat dalam meningkatkan volume penjualan. Beberapa factor yang mempengaruhi volume penjualan adalah kualitas barang dan kemampuan membaca trend pasar (Munawaroh E. R., 2016). Terkait dengan penjualan yang dilakukan UD. Rajawali Sakti dalam meningkatkan volume penjualan batu cetak, perusahaan selalu merespon dan membaca permintaan konsumen dengan memperbanyak varian produksi batu cetak.

Pelayanan yang prima menjadi salah satu modal utama yang dilakukan UD. Rajawali Sakti dalam rangka menjaring pelanggan, pelayanan yang prima ini dilakukan sebagai ciri utama perusahaan dalam menciptakan hubungan yang baik dengan konsumen, sehingga dapat meningkatkan volume penjualan.

\section{Kesimpulan}

\section{KESIMPULAN DAN SARAN}

Berdasarkan hasil penelitian dan pembahasan maka dapat disimpulkan bahwa, pemasaran yang dilakukan UD. Rajawali Sakti menggunakan Strategi Bauran pemasaran diantaranya, Produk, Promosi, Harga, dan Tempat. Sedangkan untuk meningkatkan volume penjualan Batu cetak, perusahaan selalu melakukan Inovasi dan kreatif dalam memproduksi batu cetak, dengan menambah varian batu cetak serta meningkatkan kualitas produk, selain itu perusahaan meningkatkan kualitas layanan terhadap konsumen.

\section{Saran}

Usaha meningkatkan volume penjualan menjadi target utama dalam aktifitas bisnis, untuk itu dalam menjaga keseimbangan dan keberlangsungan bisnis percetakan batu UD. Rajawali Sakti, maka perusahaan secara kontinyu harus melakukan perbaikan - perbaikan dalam hal strategi pemasaran sehingga produk yang dihasilkan mampu bersaing di pasar.

\section{DAFTAR PUSTAKA}

Boedi Abdullah dan Beni Ahmad Saebani. 2014. Metodo Penelitian Ekonomi Islam Muamalah, Bandung: Pustaka Setia, 49 (Saebani, 2014)

Burhan Bungin. 2013. Metodologi Penelitian Sosial dan Ekonomi, Jakarta: PT. Prenada Media Group, 129. (Bungi, 2013)

Erwinsyah Riskan Fahlevi, R.R. Siti Munawaroh. 2016. Strategi Pemasaran untuk menginkatkaN Volume Penjualan, Jurnal manajemen dan Akuntansi, Volume 17, Nomor 01, 13. (Erwinsyah Riskan Pahlevi, 2016)

Lexy, J, Moleong. 2012. Metodelogi Penelitian Kualitatif, Edisi Revisi (Bandung: PT. Remaja Rosdakarya, 157. (Lexy, 2012) 
Nana herdiana Abdurrahman. 2015. Manajemen strategi pemasaran. Bandung, CV: Pustaka setia, 14-15. (Abdurrahman N. H., manajemen strategi pemasaran, 2015)

S. Nasution, Metode Resech, (Penelitian Ilmiah), (Jakarta: Bumi Aksara, 2012), 105. (Nasution, 2012)

Sudaryono. 2016. Manajemen Pemasaran: Teori \& Implementasi. Yogya karta: Penerbit Andi (Sudaryono, 2016)

Suharno \& Santoso, Y. 2010. Marketing in Practice. Yogyakarta: Graha Ilmu (Suharno \& Santoso, 2010)

Sugiyono. 2012. Metode Penelitian Bisnis: Pendekatan Kuantitatif, Kualitatif, dan R\&D, Bandung: Alfabeta (sugiyono, 2012)

Tjiptono, Fandy dan Gregorius Chandra. 2012. Pemasaran Strategik, Edisi Kedua, Yogyakarta (Tjiptono, 2012) 